\title{
PENGARUH SEPARATOR TERHADAP KINERJA LALU LINTAS DI JALAN PERKOTAAN
}

\author{
Louise Elizabeth Radjawane ${ }^{* 1}$ \\ ${ }^{1}$ Dosen, Program Studi Teknik Sipil, Jurusan Teknik Sipil, \\ Universitas Kristen Indonesia Paulus Makassar \\ Korespondensi : eliz_louise@yahoo.com
}

\begin{abstract}
One of solutions to reduce traffic problems on Jl.AP.Pettarani, Makassar is the separation of paths based on their functions (fast and slow lanes) or called separator. The purpose of this study is to determine the traffic performance at the separator openings, the effect of the length of the separator openings on the degree of saturation and weaving speed. The performance (degree of saturation) of the separator openings based on IHCM 1997 on AP.Pettarani (direction of Sultan Alauddin - Tol Reformasi) during the morning and evening peak hours are 2,054 and 2,113. Degree of saturations for the opposite direction at morning and afternoon peak hours are 1,893 and 1,980. The addition of the length of the separator will increase weaving speed.
\end{abstract}

Keywords : Indonesia Highway Capacity Manual 1997, Weaving Speed, Separator Openings Performance, Weaving Length

\section{PENDAHULUAN}

Jalan Pettarani Kota Makassar merupakan jalan nasional dan memiliki panjang $4.37 \mathrm{~km}$. Ruas jalan ini terletak di Kelurahan Panaikkang dengan kondisi tata guna lahan adalah mixed land use dan lalu lintas yang heterogen serta tingkat aktivitas yang tinggi menyebabkan ruas jalan ini merupakan salah satu ruas jalan dengan tingkat kemacetan yang cukup tinggi di Kota Makassar. Salah satu upaya yang dilakukan untuk menangani permasalahan lalu lintas di Jl.A.P.Pettarani adalah dengan dipisahkannya jalur berdasarkan fungsinya (jalur cepat dan lambat) atau disebut dengan separator.

Tujuan penelitian untuk mengetahui kinerja lalu lintas di bukaan separator, pengaruh panjang bukaan separator terhadap derajat kejenuhan dan kecepatan jalinan di bukaan separator di Jl.A.P.Pettarani.

\section{TINJAUAN PUSTAKA}

\subsection{Karakteristik Lalu Lintas}

Arus, kecepatan, dan kerapatan merupakan karakteristik lalu lintas yang saling berkaitan dan dapat ditinjau secara makroskopik dan mikroskopik. Pendekatan makroskopik yaitu melihat arus lalu lintas secara keseluruhan dan pendekatan mikroskopik melihat respon dari setiap kendaraan secara terpisah - pisah [1]. Kerangka dasar karakteristik lalu lintas dapat dilihat pada Tabel 1.

Tabel 1.Kerangka dasar karakteristik lalu lintas

\begin{tabular}{|c|c|c|}
\hline Karakteristik & Makroskopik & Mikroskopik \\
\hline Arus & Flow Rate & Waktu Antara \\
\hline Kecepatan & $\begin{array}{c}\text { Kecepatan } \\
\text { Rata-Rata }\end{array}$ & $\begin{array}{c}\text { Kecepatan } \\
\text { Individu }\end{array}$ \\
\hline \multirow{2}{*}{ Kerapatan } & $\begin{array}{c}\text { Tingkat } \\
\text { Kerapatan }\end{array}$ & $\begin{array}{c}\text { Distance } \\
\text { Headway }\end{array}$ \\
\hline \multicolumn{2}{|l}{ Sumber: May, 1990} \\
\end{tabular}

\subsection{Jalinan}

Kapasitas total bagian jalinan adalah hasil perkalian antara kapasitas dasar pada kondisi tertentu dan faktor penyesuaian [2]. Model kapasitas jalinan dijabarkan pada persamaan (1). Pergerakan jalinan terdiri dari yaitu pergerakan menerus pada jalur cepat, pergerakan menerus pada jalur lambat, pergerakan dari jalur cepat ke jalur lambat, dan pergerakan dari jalur lambat ke jalur cepat. Pergerakan jalinan dapat dilihat pada Gambar 1. Lebar efektif jalur lalu lintas pada jalinan 
diperoleh dari rata-rata lebar jalur cepat dan jalur lambat pada bagian jalinan. Lebar dan panjang jalinan dapat dilihat pada Gambar 2.

$\mathrm{C}=135 \times \mathrm{W}_{\mathrm{w}}^{1,3} \times\left(1+\left(\mathrm{W}_{\mathrm{e}} / \mathrm{W}_{\mathrm{w}}\right)^{1,5} \times\left(1-\mathrm{p}_{\mathrm{w}} / 3\right)^{0,5} \times\right.$
$\left(1+\mathrm{W}_{\mathrm{w}} / \mathrm{L}_{\mathrm{w}}\right)^{-1,8} \times \mathrm{F}_{\mathrm{cs}} \times \mathrm{F}_{\mathrm{rsu}}$

Dimana : $\mathrm{C}=$ Kapasitas

$\mathrm{Ww}=$ Lebar jalinan $(\mathrm{m})$

$\mathrm{We} \quad=$ Lebar masuk rata-rata $(\mathrm{m})$

$\mathrm{LW} \quad=$ Panjang jalinan $(\mathrm{m})$

$\mathrm{Pw} \quad=$ Rasio jalinan

FCS = Faktor ukuran kota

$\mathrm{F}_{\mathrm{RSU}} \quad=$ Faktor hambatan samping

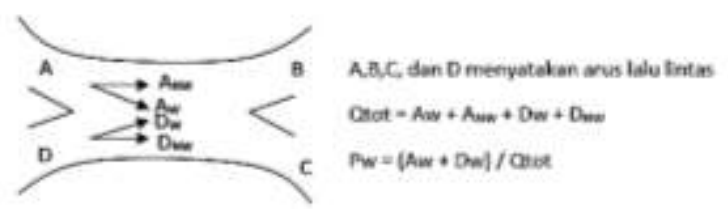

Gambar 1. Pergerakan jalinan

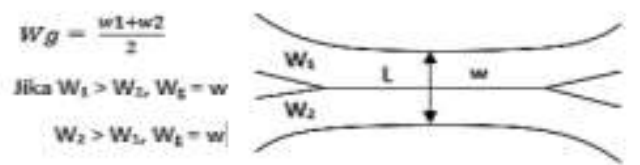

Gambar 2. Lebar dan panjang jalinan

Faktor penyesuaian ukuran kota dibedakan berdasarkan jumlah penduduk, Faktor penyesuaian ukuran kota dapat dilihat pada Tabel 2.

Tabel 2.Faktor penyesuaian ukuran kota $\left(\mathrm{F}_{\mathrm{CS}}\right)$

\begin{tabular}{|c|c|c|}
\hline $\begin{array}{c}\text { Ukuran Kota } \\
(\mathrm{CS})\end{array}$ & $\begin{array}{c}\text { Penduduk } \\
\text { Juta }\end{array}$ & $\begin{array}{c}\text { Faktor Penyesuaian } \\
\text { Ukuran Kota (Fcs) }\end{array}$ \\
\hline Sangat kecil & $<0,1$ & 0,82 \\
\hline Kecil & $0,1-0,5$ & 0,88 \\
\hline Sedang & $0,5-1,0$ & 0,94 \\
\hline Besar & $1,0-3,0$ & 1,00 \\
\hline Sangat Besar & $>3,0$ & 1,05 \\
\hline
\end{tabular}

Faktor hambatan samping serta rasio kendaraan tak bermotor dibedakan berdasarkan tipe lingkungan. Faktor hambatan samping dan kendaraan tak bermotor berdasarkan kelas tipe lingkungan jalan, kelas hambatan samping, dan rasio kendaraan tidak bermotor. Faktor hambatan samping disajikan pada Tabel 3 .

Tabel 3. Faktor hambatan samping dan rasio kendaraan tak bermotor $\left(\mathrm{F}_{\text {rsu }}\right)$

\begin{tabular}{|c|c|c|c|c|c|c|c|}
\hline \multirow{2}{*}{ 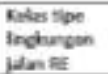 } & \multirow{2}{*}{$\begin{array}{l}\text { Files } \\
\text { hanubutan } \\
\text { semping SF }\end{array}$} & \multicolumn{6}{|c|}{ 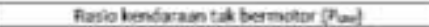 } \\
\hline & & $\operatorname{sen}$ & ces & a.so & 0.25 & 0.20 & 2025 \\
\hline \multirow{3}{*}{ Conmial } & Tere: & ass & 0.00 & ast & $a x$ & 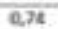 & 0,0 \\
\hline & Sendene & est & as & a.s & $m$ & 0.75 & 0,20 \\
\hline & Amodyh & $\cos$ & 000 & $\cos$ & $\cos$ & $0 . x$ & an \\
\hline \multirow{3}{*}{ Renudituan } & Thers & es6 & 0,91 & DS6 & 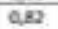 & $c \pi$ & $2 \pi$ \\
\hline & Seldere & Q997 & 092 & $\operatorname{cog}$ & $\Leftrightarrow$ & $0 \pi$ & 2,73 \\
\hline & Entah & ess & ass & $\cos$ & axs & a.n & 0,74 \\
\hline $\begin{array}{l}\text { Nobes } \\
\text { terbatm }\end{array}$ & $\begin{array}{l}\text { Trues } \\
\text { Sedens } \\
\text { Rinten }\end{array}$ & 200 & $\cos$ & $=00$ & ess & $\cos$ & $e \pi$ \\
\hline
\end{tabular}

\subsection{Separator}

Fungsi pemisah jalur [3] adalah meningkatkan keselamatan, kelancaran, dan kenyamanan pemakai jalan dan lingkungan, mempertahankan pemanfaatan jalur lalu lintas sesuai dengan fungsi jalannya. Bukaan pemisah jalur adalah jalur lalu lintas sepanjang separator, dipergunakan untuk pergerakan kendaraan yang akan membelok atau balik arah, adanya dua jalur jalan yang saling berbeda fungsi dalam satu arah, dan danya gangguan hambatan samping terhadap jalur utama.

Aspek geometri

- Pemisah jalur direncanakan untuk mengakomodasi kendaraan rencana, terutama dalam manuver saat kendaraan melakukan perpindahan jalur;

- Kecepatan rencana digunakan dalam penyesuaian ciri-ciri fungsi dan penentuan jarak bukaan separator;

- Lebar jalur direncanakan untuk menjaga kelancaran lalu lintas.

Dimensi bukaan pemisah jalur [4] yaitu jarak bukaan minimum, lebar bukaan, dan panjang bukaan untuk daerah perkotaan dan daerah luar kota dibedakan berdasarkan fungsi jalan utama disajikan pada Tabel 4. 
Tabel 4. Dimensi bukaan pemisah jalur [4]

\begin{tabular}{|c|c|c|c|c|c|c|}
\hline \multirow{2}{*}{\begin{tabular}{c} 
Fungsi \\
Jalan \\
\cline { 2 - 7 }
\end{tabular}} & $\begin{array}{c}\text { Jarak Bukaan } \\
\text { Minimum }(\mathrm{m})\end{array}$ & $\begin{array}{c}\text { Lebar Bukaan } \\
\text { Minimum } \\
(\mathrm{m})\end{array}$ & $\begin{array}{c}\text { Panjang } \\
\text { Bukaan }(\mathrm{m})\end{array}$ & $\begin{array}{c}\text { Jarak Bukaan } \\
\text { Minimum (m) }\end{array}$ & $\begin{array}{c}\text { Lebar } \\
\text { Bukaan } \\
\text { Minimum } \\
(\mathrm{m})\end{array}$ & $\begin{array}{c}\text { Panjang } \\
\text { Bukaan }(\mathrm{m})\end{array}$ \\
\hline Arteri & 400 & 6 & 12 & 500 & 6 & 12 \\
\hline Kolektor & 300 & 5 & 10 & 400 & 5 & 10 \\
\hline
\end{tabular}

\subsection{Penelitian Sebelumnya}

Golob, T.F., Wilfred.E.Recker, dan Veronica M.Alvares [5] melakukan penelitian aspek keselamatan bagian jalinan di jalan bebas hambatan menghasilkan faktor kecelakaan di bagian jalinan terjadi kecelakan bagian samping kendaraan dengan kejadian tertinggi di jalur dalam. Al-Jameel [6] membuat model manajemen jalinan tipe A dan B berdasarkan Highway Capacity Manual, 2000, menghasilkan peningkatan tingkat kecepatan dan penurunan panjang antrian. Skabardonis A, dan Mauch M [7] melakukan penelitian di 93 titik jalinan dengan hasil rata-rata $24 \%$ dari titik tersebut dengan Metode HCM 2000 lebih dapat memprediksi kepadatan lalu lintas di jalinan dengan nilai $13,4 \%$, sedangkan metode Tingkat $\mathrm{D}$ dan Leisch sebesar 3\%. Mao, Yuan, Gan, dan Zhang [8] melakukan penelitian mengenai faktor resiko penyebab kecelakaan di segmen jalinan menghasilkan kepadatan lalu lintas $\geq 31$ kendaraan/100 m memiliki resiko tertinggi kecelakaan ujung belakang, rasio jalinan $\geq 41 \%$ memiliki peluang terbesar kecelakaan dari samping. Cai,Q., Saad, M., Abdel-Aty, M., dan
Yuan, J., [9] menggunakan simulasi VISSIM untuk mengetahui panjang jalinan optimal berkaitan dengan aspek keselamatan di jalan bebas hambatan, menghasilkan panjang optimal setiap pergantian lajur $\left(\mathrm{L}_{\mathrm{LC}}\right)$ adalah 1000 kaki memberikan kinerja keselamatan lalu lintas terbaik dengan tingkat konflik terendah.

\section{METODOLOGI PENELITIAN}

Pelaksanaan waktu survey dipilih berdasarkan pertimbangan jam sibuk pagi dan sore, sehingga penentuan titik dan pemilihan waktu akan mencerminkan pola pekerjaan yang sebenarnya.

Pelaksanaan survey volume lalu lintas di 24 titik bukaan separator Jl.A.P.Pettarani ditentukan pada jam sibuk pagi dan sibuk sore sebagai berikut:

- pukul 06:30 - 08:30

- pukul 16:00 - 18:00

Lokasi penelitian diperlihatkan pada Gambar 3.

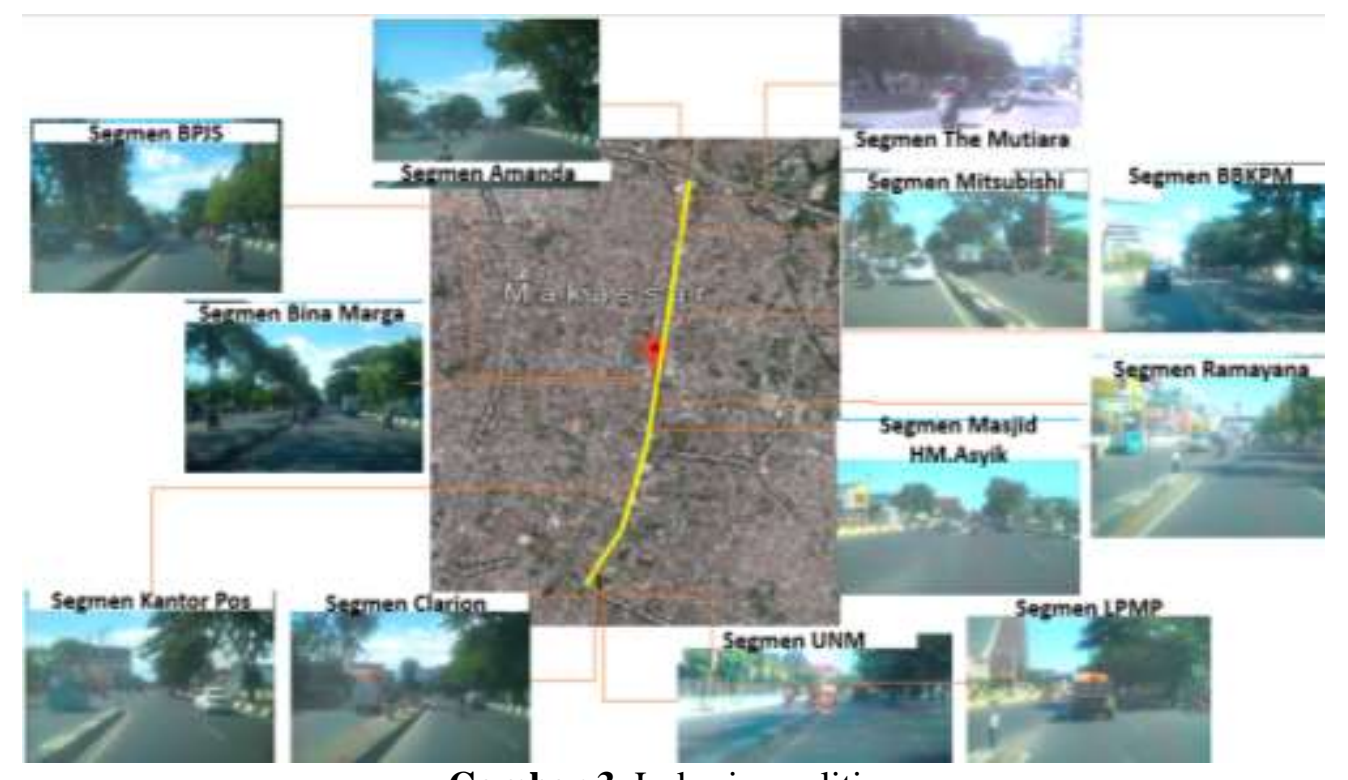

Gambar 3. Lokasi penelitian 


\section{HASIL DAN PEMBAHASAN}

\subsection{Volume Kendaraan}

Banyaknya mid-block dan fasilitas arah putar balik (u-turn) di ruas Pettarani bukan hanya mempengaruhi arah menerus lalu lintas tetapi menimbulkan pergerakan jalinan saat kendaraan dari mid-block akan melakukan pergerakan balik arah (u-turn). Pada saat kendaraan akan melakukan gerakan balik arah, ,diawali dengan gerakan bergabung dengan arah menerus lalu lintas, yang kemudian melakukan pemisahan dari lalu lintas menerus pada bukaan separator. Hal yang sama juga berlaku untuk pergerakan dari bukaan separator akan menuju ke mid-block. Volume kendaraan di separator untuk jalur arah Jl.Pettarani (Tol Reformasi) - Jl.Sultan Alauddin pada jam sibuk pagi antara 4424 smp/jam dan 9144 smp/jam. Volume tertinggi terjadi di separator segmen Dinas Koperasi dan volume terendah terjadi di separator segmen Hino. Volume yang terdapat pada separator segmen Dinas Koperasi terdapat tambahan volume dari persimpangan Jl.Pengayoman Pettarani. Pada jam sibuk sore hari volume lalu lintas kembali mengalami peningkatan, volume terpadat pada separator segmen BNI sebesar $8688 \mathrm{smp} / \mathrm{jam}$.

Untuk Jl.Pettarani dengan arah dari Jl.Sultan Alauddin menuju Jl. Pettarani (Tol Reformasi), volume kendaraan tertinggi pada jam sibuk pagi dan sore masing-masing terjadi di bukaan separator segmen Kantor Bina Marga dengan nilai 10.617 smp/jam dan segmen Universitas 17 Agustus dengan nilai 9699 smp/jam. Volume kendaraan pada separator segmen Bina Marga adalah volume kendaraan dari ruas Jl.Pettarani dengan beberapa penambahan dari Jl.Pelita Raya dan Jl. Boulevard serta $U$-turn yang semuanya akan menuju Tol Reformasi. Sedangkan volume kendaraan pada separator segmen Universitas 17 Agustus berasal dari volume kendaraaan ruas Jl.Pettarani (dari arah Jl.Sultan Alauddin) ditambah dengan volume kendaraan dari arah Jl.Hertasning yang masuk ke Jl.Pettarani dan volume kendaraan dari arah Jl. Rappocini Raya yang masuk ke Jl.Pettarani. Untuk sore hari volume terbesar pada segmen BPJS dengan nilai 8842 smp/jam. Volume ini juga dari tambahan volume simpang Sungai Saddang.

Dari nilai volume kendaraan pada jam sibuk terlihat prosentase arah dari Jl. Pettarani (Tol Reformasi) - Sultan Alauddin sebesar $46 \%$ dan arah sebaliknya sebesar $54 \%$. Hal ini dikarenakan area perkantoran banyak terdapat di Ruas Pettarani, arah Alauddin - Tol Reformasi.

Banyaknya persimpangan yang terdapat sepanjang ruas Jl. Pettarani memberikan kontribusi yang cukup besar/berpengaruh terhadap volume kendaraan pada bukaan pemisah jalur di Jl.Pettarani.

Rekapitulasi volume lalu lintas di bukaan pemisah jalur Jl.Pettarani dapat dilihat pada Gambar 4.

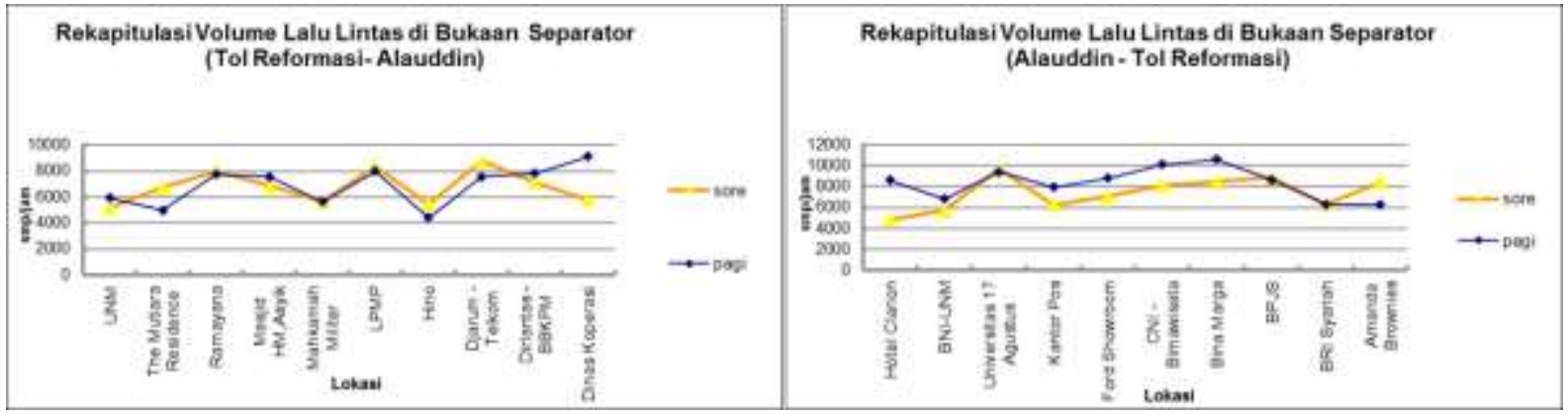

Sumber : Hasil Analisa

Gambar 4. Rekapitulasi volume lalu lintas di bukaan separator Jalan Pettarani 


\subsection{Kinerja bukaan separator}

Lalu lintas yang heterogen dan tingginya hambatan samping di ruas Pettarani sangat mempengaruhi kinerja lalu lintas. Seperti parkir di badan jalan, angkutan kota yang menaikturunkan penumpang tidak pada tempatnya, kurangnya lahan parkir pada bangunan-bangunan, sistem sirkulasi lalu lintas internal bangunan yang kurang efisien sehingga menganggu arus lalu lintas eksternal, dan penyeberang jalan yang tinggi (di ruas Pettarani terdapat satu jembatan penyeberangan orang, namun kondisi JPO yang kurang memberi kenyamanan dan keamanan untuk penyeberang jalan, sehingga penyeberang jalan lebih memilih untuk tidak mengggunakan fasilitas JPO).

Dari hasil analisa perhitungan kinerja jalinan di bukaan separator ruas JL. Pettarani (arah Sultan Alauddin - Tol Reformasi) diperoleh kondisi terjenuh pada jam sibuk pagi dan sore pada bukaan separator segmen Bina Marga dengan masing-masing nilai derajat kejenuhan 2,054 dan 2,113, serta nilai kecepatan jalinan berturut-turut $0,41 \mathrm{~km} / \mathrm{jam}$ dan $0,86 \mathrm{~km} / \mathrm{jam}$.

Untuk arah sebaliknya, separator segmen Mitsubishi memiliki nilai derajat kejenuhan terbesar pada jam sibuk pagi dan sore hari, masing-masing dengan nilai 1,893, dan 1,980. Nilai kecepatan kedua jam sibuk tersebut untuk segmen Mitsubishi, berturut-turut $0,84 \mathrm{~km} / \mathrm{jam}$ dan $0,15 \mathrm{~km} / \mathrm{jam}$. Kinerja jalinan setiap bukaan separator kondisi jam sibuk pagi dan sore disajikan pada Tabel 5 dan Tabel 6.

\subsection{Pengaruh Panjang Bukaan Separator Terhadap Kinerja Jalinan}

Panjang bukaan separator ruas Jl.Pettarani bervariasi antara $20 \mathrm{~m}$ dan $55 \mathrm{~m}$. Bukaan separator terpanjang yaitu pada separator segmen Djarum - Telkom dengan panjang $55 \mathrm{~m}$ (arah Jl.Tol Reformasi - Sultan Alauddin), sedangkan bukaan separator terpendek dengana nilai $21 \mathrm{~m}$ terletak disegmen Hino, Bina Marga, Universitas 17 Agustus, dan RS. Paramount. Salah satu faktor yang mempengaruhi kinerja pada bukaan separator adalah panjang bukaan separator. Bertambahnya panjang bukaan separator mengakibatkan kinerja jalinan semakin baik. Hasil persamaan linear hubungan antara panjang bukaan separator dan derajat kejenuhan adalah $-0,0268 x+2,3088$, (nilai $R^{2}=$
0,5414). Hubungan antara panjang bukaan separator dan derajat kejenuhan dapat dilihat pada Gambar 5.

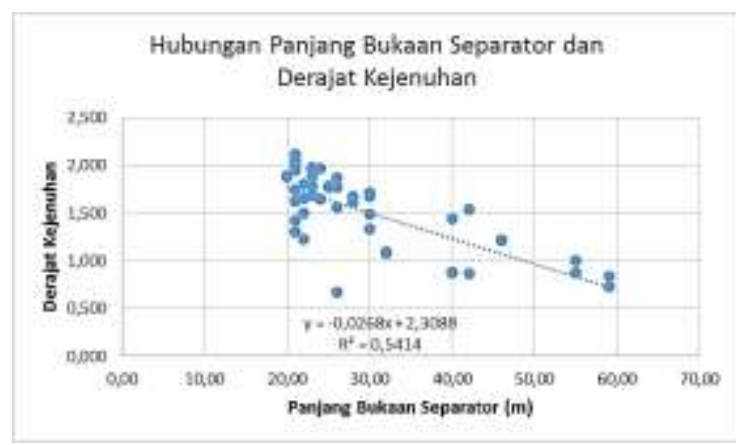

Sumber : Hasil Analisa

Gambar 5. Hubungan antara panjang bukaan separator dan derajat kejenuhan

Gambar 6 menunjukkan hubungan antara panjang jalinan dan kecepatan. Dari gambar tersebut, terlihat bahwa kecepatan akan menurun jika panjang bukaan separator berkurang. Dimana persamaan linier yang dihasilkan yaitu $-1,0339 x+24,088$ dengan nilai $\mathrm{R}^{2}=0,3346$. Pada bukaan separator yang pendek, kecepatan kendaraan yang akan melakukan jalinan sulit menyesuaikan dengan kecepatan arah lalu lintas menerus, sehingga kendaraan yang akan melakukan pemisahan/pemotongan dari/terhadap arah lalu lintas menerus harus berjalan dengan kecepatan rendah bahkan berhenti sejenak untuk menunggu arus lalu lintas menerus memberikan ruang untuk kendaraan tersebut melakukan pergerakan jalinan. Pada kondisi inilah menganggu pergerakan lalu lintas di belakang kendaraan yang akan melakukan jalinan.

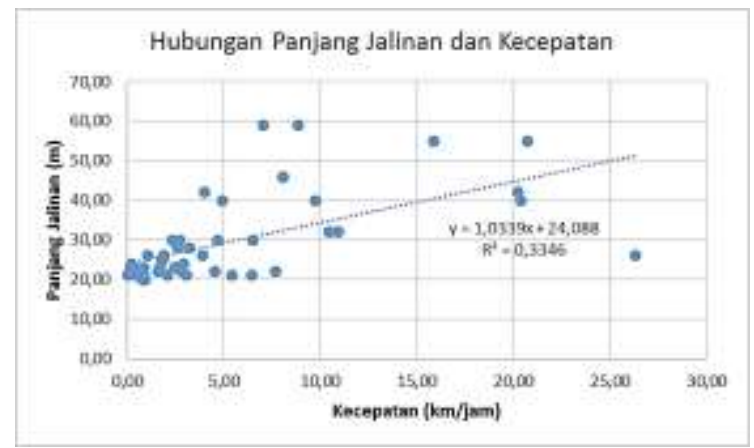

Sumber : Hasil Analisa

Gambar 6. Hubungan antara panjang bukaan separator dan kecepatan 


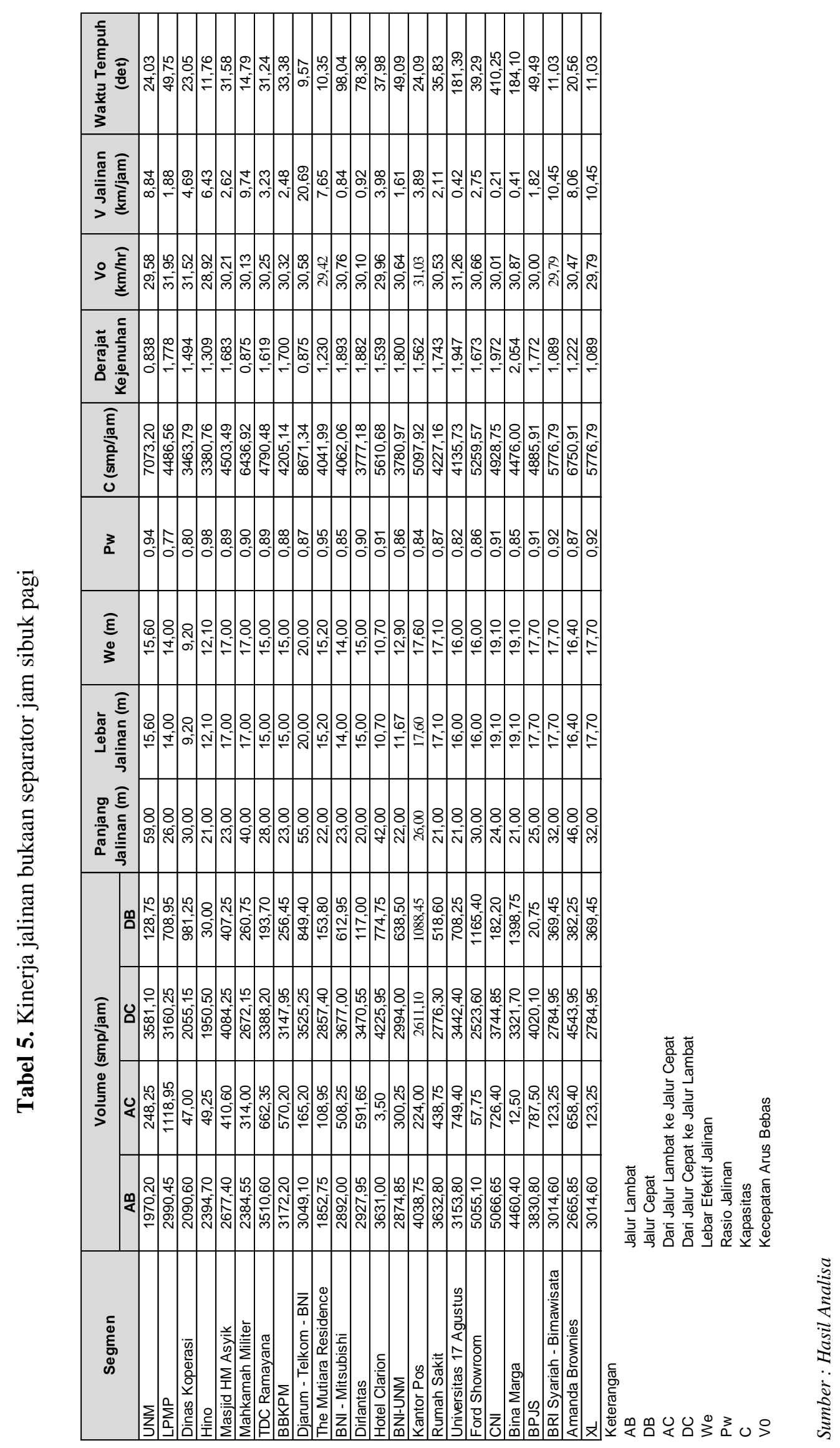




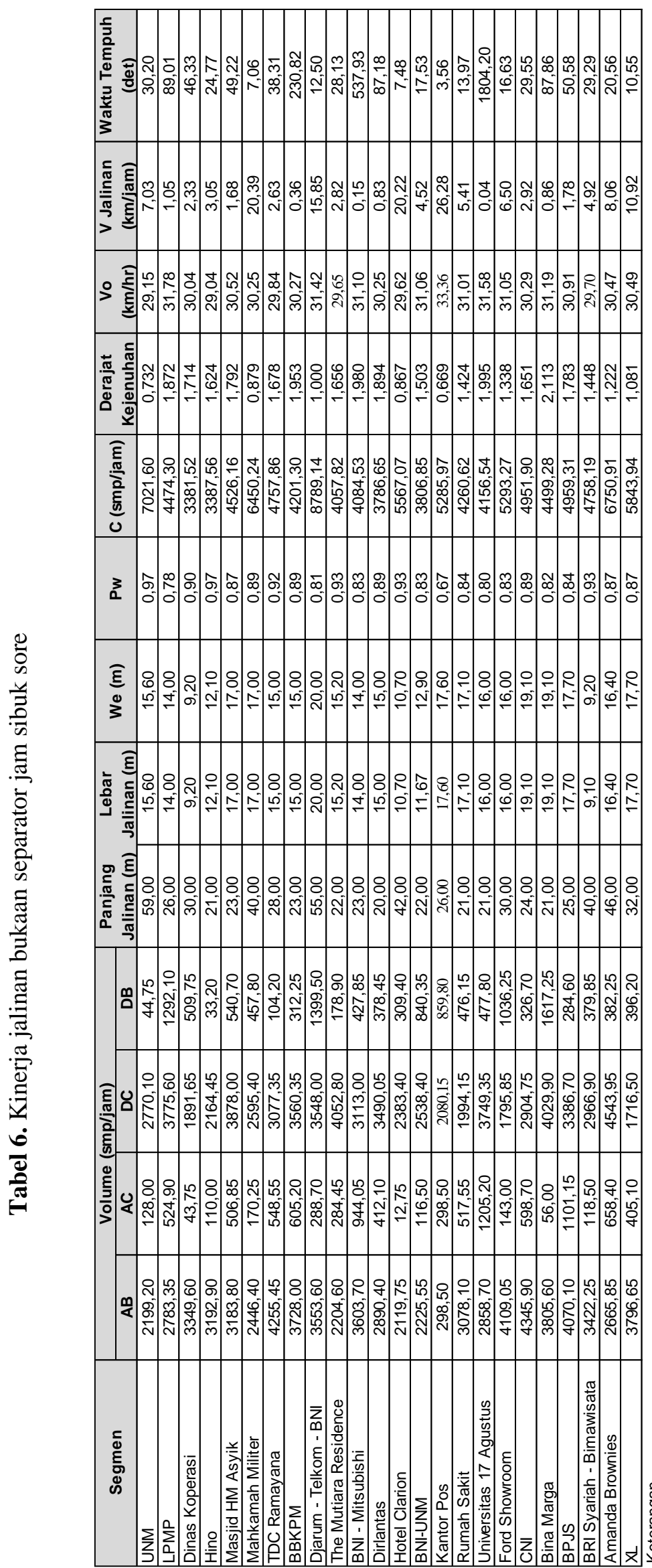

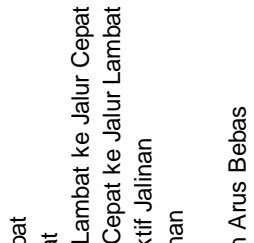
可

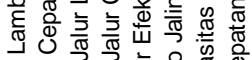

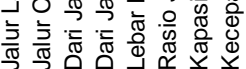




\section{KESIMPULAN DAN SARAN 5.1. Kesimpulan}

Persentase distribusi arah volume kendaraan pada jam sibuk Jl. Pettarani - Sultan Alauddin sebesar $46 \%$ dan arah sebaliknya sebesar 54\%.

Panjang separator ruas Jl.Pettarani bervariasi antara $20 \mathrm{~m}$ dan $55 \mathrm{~m}$. Bukaan separator terpanjang yaitu pada separator segmen Djarum - Telkom dengan panjang $55 \mathrm{~m}$ (arah Jl.Tol Reformasi - Sultan Alauddin), sedangkan bukaan separator terpendek dengan nilai $21 \mathrm{~m}$ terletak di bukaan separator segmen Hino, Bina Marga, Universitas 17 Agustus, dan RS. Paramount.

Kinerja jalinan di bukaan separator ruas JL. Pettarani (arah Sultan Alauddin - Tol Reformasi) diperoleh kondisi terjenuh pada jam sibuk pagi dan sore pada bukaan separator segmen Bina Marga dengan masing-masing nilai derajat kejenuhan 2,054 dan 2,113. Untuk arah sebaliknya, separator segmen Mitsubishi memiliki nilai derajat kejenuhan terbesar pada jam sibuk pagi dan sore hari, masing-masing dengan nilai 1,893 dan 1,980.

Penambahan panjang bukaan separator mengakibatkan kinerja jalinan semakin baik. Persamaan linear hubungan antara panjang bukaan separator dan derajat kejenuhan adalah $-0,0268 x+2,3088$, (nilai $R^{2}=0,5414$ ).

Kecepatan akan menurun jika panjang bukaan separator berkurang. Persamaan linier yang dihasilkan antara kecepatan dan panjang bukaan separator yaitu $-1,0339 x+24,088$ dengan nilai $\mathrm{R}^{2}=0,3346$.

\subsection{Saran}

Untuk penelitian selanjutnya, metode analisis pergerakan jalinan di Jl. AP.Pettarani,
Makassar dapat menggunakan metode analisis pergerakan jalinan lainnya, sehingga hasil dari masing-masing metode dapat dibandingkan.

\section{DAFTAR PUSTAKA}

[1] May, Adolf, Traffic Flow Fundamentals, Prentice Hall, New Jersey, 1990 : 4.

[2] Departemen Pekerjaan Umum, Manual Kapasitas Jalan Indonesia, Jakarta, 1997 : halaman 4-16 - 4-25.

[3] SNI - 03 - 2444 - 2002, SNI Spesifikasi Bukaan Pemisah Jalur, Jakarta, 2002.

[4] Departemen Permukiman dan Prasarana Wilayah, Pd-T-15-2004-B, SNI Pedoman Perencanaan Separator Jalan, Jakarta, 2004 : halaman 8-13.

[5] Golob, T.F., Wilfred.E.Recker, dan Veronica M.Alvares, Safety Aspects of Freeway Weaving Sections University of California, 2003.

[6] Al-Jameel, H., A., E., Contribution to The Weaving Area Management Using Microscopic Simulation Model, Journal of Babylon, University/Engineering Sciences/No.3/Vol.23, 2015.

[7] Skabardonis,A,. and Mauch,M., Evaluation of Methodologies for Analyzing Freeway Ramp Weaving, Transportation Research Record Journal of The Transportation Research Board 2484 (2483), 2015 : 130-139.

[8] Mao,X., Yuan,C., Gan,J., dan Zhang,S., Risk Factors Affecting Traffic Accidents at Urban Weaving Sections : Evidence from China, International Journal of Environmental Research and Public Health, 2016: 1542.

[9] Cai, Q., Saad, M., Abdel-Aty, M., dan Yuan, J., Safety Impact of Weaving Distance on Freeway Facilities with Managed Lanes Using Both Microscopic Traffic and Driving Simulations, Transport Research Record Journal Transportation Research Board, DOI: 10.1177/0361198118780884, 2018. 